\title{
Student Initiative Empowers Engagement for Learning Online
}

\author{
Houston Heflin \\ Suzanne Macaluso \\ Abilene Christian University, Abilene, Texas
}

\begin{abstract}
Assessing the degree to which students engage and learn from their online courses will be important as online courses are becoming more ubiquitous. This study sought to capture student perceptions of their independence as learners, their level of engagement, their effort exerted, and the amount of information they learned in online courses. The study was conducted over three years with 455 students who completed a self-assessment at the end of an intensive summer online course. Results showed an equal number of students agreeing and disagreeing that online courses help students learn the same amount of information encountered in a face-to-face course. The majority of students reported they were more independent $(84.4 \%)$, were more engaged $(54.5 \%)$ and exerted more effort (57.4\%), in their online course than a typical face-to-face class. Recommendations are made for faculty creating online courses who have the opportunity to coach students on how to succeed in the online learning environment.
\end{abstract}

Keywords: Distance education, pedagogical issues, adult learning, teaching/learning strategies

Heflin, H, \& Macaluso, S. (2021). Student initiative empowers engagement for learning online. Online Learning, 25(3), 230-248. doi:10.24059/olj.v25i3.2414 
Online learning is growing in popularity among students (Bednar, 2018) and is predicted to be a growing market for academic institutions for the foreseeable future (Technavio Research, 2019). A 2018 study reported that distance education enrollments increased for the fourteenth consecutive year, with the most recent years seeing the most significant increase, even as overall college enrollment was declining (Seaman et al., 2018). Then, in the spring of 2020, many colleges were forced to create online courses or components of courses in response to the social distancing requirements during the COVID-19 pandemic. Many faculty members responded to this need by creating online learning experiences for students. Teachers continue using technology to build online courses where students are engaged and learning, which generally asynchronous interactions make especially challenging. The asynchronous nature of online learning in particular highlights how important student motivation is to student engagement (Al Tawil, 2019; Choi, 2016). Some students struggle to engage with material when attendance is not tied to a specific time, but online learning is also challenging considering the reputation among some students that computer-assisted learning is inferior to, or less rigorous than, face-to-face (F2F) learning (Allen et al., 2016). Some students still approach online learning with this assumption, reasoning that because no face-to-face sessions happen, the course will be less demanding on time, it will be less difficult academically, and it will require less effort (Bawa, 2016). These perceptions may be based on past experiences of poorly designed courses, or based on assumptions tied to the online method of instruction. But if perception of their experiences is the reality for students, then what they perceive about their online courses matters, and evidence suggests there is room for continued improvement in the student experience with online learning (Sarraf et al., 2019). The current study sought to capture student perceptions of their online learning experience in several categories.

\section{Review of Literature}

Students' perceptions of their learning experiences are important to gather, especially beliefs about a course's value and how interesting it is (Yang et al., 2011). Course assessment is a vital tool that helps students succeed in online education and can improve the quality of future courses (Yarbrough, 2018). The current study emerged from the desire to glean those perceptions of students' own independence, engagement, effort, and learning in online courses in order to evaluate the efficacy of these online courses. Considering this, the following literature review focuses on three areas: independence as a hallmark of adult learning, student engagement, and course design.

\section{Independence and Adult Learning}

Online courses are, by their very nature, constructed in ways that depend on students to be responsible and access information in isolation, independent of other learners (Yarbrough, 2018). Within this isolation students find their own initiative, or motivation, for consistently engaging the course. They must be "self-regulated...developing agency and be responsible for their own learning" (Cohen \& Jackson-Haub, 2019, p. 1). Students who understand their own independence grasp an important component of learning that helps them be successful (Buelow et al., 2018). In other words, the best recipe for student engagement is for students to view online courses as "instructor facilitated and student owned" (Schroeder-Moreno 2010, p. 28) as students take initiative and responsibility for their learning.

Adult learning theory acknowledges the importance of student initiative and independence. It does this by distinguishing between pedagogy (learning by children and adolescents) and andragogy (learning by adults). Adult learners differ from children in six 
important ways (Knowles et al., 2005). Specifically, 1) adults need to understand why they need to learn something, 2) adults have a self-concept of being responsible for their learning, 3) adults approach learning with a wealth of experience, 4) adults are ready to learn applicable content, 5) adults are life-centered (or problem-centered) in their orientation to learning, and 6) adults are motivated intrinsically to pursue learning. Adults have tools at their disposal to be successful in learning that some younger learners do not have. These are primarily experience, study habits that work for them, and the initiative to pursue learning. Of all these, motivation seems to be the characteristic that fuels their resilience to succeed in courses.

Motivation is essential to adult education because adult learners want to know that an investment in learning is relevant to their lives and valuable in helping them accomplish goals. They want learning to connect with their own experiences and they want to feel respected as competent learners with agency in the process. Students are more likely to feel motivated and engage in learning when these standards are met (Smith, 2017).

Online research not focused on adult learning has identified tools successful learners have that happen to be some of the hallmarks of adult learning. For example, online courses require students to have skills in time management, self-motivation (Bednar, 2018), self-imposed academic discipline, self-directed learning, and initiative (Bawa, 2016). These comprise characteristics of successful adult learners. Similarly, Lehman and Conceição's persistence model for online student retention identifies five student qualities for successful learning: selfawareness, self-efficacy, goals, means to achieve those goals, and rewards along the way (2014). Adult learners motivated to achieve learning frequently possess these characteristics.

The strongest predictors of course achievement in one study included "self-regulated learning, particularly regular study in accordance with the course schedule, the timely completion of assigned tasks, frequent accessing of course materials, and the reading of important course information" (You, 2016, p. 27). In online course environments, procrastination and the inability to take initiative for learning often result in less engagement and less learning. In short, time management is essential for student success (Lehman \& Conceição, 2014).

\section{Student Engagement and Effort}

The educational value of engagement has led some to claim it is one of the most important variables for student learning (Kucuk \& Richardson, 2019), while Shulman (2002) has declared that student learning begins with engagement. Said another way, engaged students are more likely to learn (Cohen \& Jackson-Haub, 2019). This awareness of the vital role of engagement has inspired the annual National Study of Student Engagement in an effort to assess how, and how well, students are learning (Indiana University School of Education, 2019). Engagement matters because it often signals student effort, or grit (Fosnacht et al., 2017). In addition, disengaged students in online classes put themselves at risk of lower grades and less learning. Disengaged students also put faculty at risk of lower course evaluations (Stott, 2016).

While online student engagement is vital to learning, a single, universally accepted definition for engagement does not exist (Halverson, 2019), and online engagement may not be the same as in-person class engagement. Evidence suggests that online courses may work well to elicit certain types of student engagement like individual learning strategies and quantitative reasoning while not eliciting other types of engagement to the same degree, such as interactions with faculty and others with diverse perspectives (Dumford \& Miller, 2016). "Student disposition" variables such as expectations for participation as well as "motivational, affective, social, and/or cultural" variables also influence student engagement (Chen et al., 2018, p. 28). These include the quality of the learning experiences in the course. Ultimately, student 
perceptions of online courses are important because students who feel unsupported or discouraged may not persist within a course (Stevenson, 2013). How students interact with the content of a course by engaging the material provided remains an area of research to be explored (Xiao, 2017).

\section{Course Design for Learning}

One of the ways to inspire student learning is to design a quality course that requires students to consistently connect with each other, with the instructor, and with the content of the course (Everett, 2015; Groccia, 2018; Buelow et al., 2018). These are, even in F2F classes, "the three parties to the conversation: the teacher, the students, and the subject itself' (Palmer, 1993, p. 98). And yet, one of the challenges of online courses is "the creation of a community of support...in a virtual space without the personal relationships often formed in face-to-face meetings" (Stevenson, 2013, p. 24). Because a lack of personal relationships can lead students to feel isolated, course design should take this into account and provide various methods of connection with the content, with peers, and interactions with the instructor (Collins et al., 2019). Students seek connection, which is achieved through engagement (Buelow, 2018). "Student engagement takes many forms" and includes cognitive, affective, and behavioral aspects of interaction with the course (Groccia, 2018, p. 18), but again, it is facilitated by quality course design.

Students are more likely to thrive when teachers communicate manageable expectations, explain clear directions, and set due dates. Conversely, overwhelming tasks and unclear instructions dampen student independence, and subsequently, negatively impact student learning (Buelow, 2018). For this reason, it is not in the students' best interests for faculty members to simply transfer a F2F course into an online course without careful consideration of the student experience in taking that course. Online courses are "different animals" (Jackson, 2019, p. 13) that require instructional designers to build them through the lens of the student experience to promote collaboration with other students and learning (Bawa, 2016). To achieve this goal, it is important to incorporate diverse student-centered strategies for learning such as faculty lectures, projects, assignments, and quizzes (Sato et al., 2019). It is also important to have a diversity of learning experiences, including cooperative learning (discussions and group projects), simulations and gaming (progression toward a goal with achievements), and multimedia tools such as videos (Davis et al., 2018). These diverse activities should take learning theories into account (Shrivastava \& Shrivastava, 2017), flow directly from course outcomes, and be designed to engage students (Stone \& Springer, 2019). Online courses that use a diversity of teaching and learning strategies (such as video lectures, case studies, multimedia resources, and challenging activities) contribute to higher student engagement (Bolton \& Gregory, 2015).

Online discussion forums are a staple feature of many courses. They assist students, not only with encountering course content, but also with encountering diverse others taking the course. Students benefit from engaging in reflexivity and awareness of themselves while interacting with fellow students in the online context (Kahn et al., 2017). As students take courses in social and geographic contexts around the world, they inform course discussions with important perspectives that need to be heard (Deschaine \& Whale, 2017). But online education also presents challenges. For example, in 2018 the National Study of Student Engagement surveyed over 3,500 undergraduate students to investigate the quality of online education (Sarraf et al., 2019). Researchers observed that students do not use all the possible engagement strategies they could for successful learning, such as asking questions (self-quizzing) and seeking answers from course readings (note taking), exchanging ideas with fellow students (discussions), and 
communicating with instructors. And yet, these are the behaviors online courses are intended to inspire in students through tools like quizzes, discussions, opportunities for note-taking, and emailing or asking questions of instructors. Course design can facilitate and enable learner engagement but whether students engage or not is driven by other forces of motivation within them.

\section{Current Study}

This study sought to capture the perspectives of students as they consider the differences that exist between their behaviors in F2F and online courses. This is not to make the two types of courses the same, but rather to propose practices intended to increase student engagement and success in online learning contexts. Other studies have also sought to capture student perceptions of various parts of the online experience, including student learning, student engagement (Martin et al., 2018), levels of self-regulated learning, and the amount of content learned $(\mathrm{Ng} \mathrm{\&}$ Baharom, 2018). These studies focused on the influence of faculty communication and leadership and adult learners respectively. Students' perceptions of their agency in online learning continues to be an important research area (Xiao, 2017; Khan et al., 2017).

This paper is a response to the need for continued assessment of students' perceptions as they are learning. Specifically, this research reports on student perceptions of their own independence, engagement, and effort in their online courses. The research also gave students the opportunity to comment on the amount of their learning in online courses. The primary questions guiding the research were:

1. How do students perceive their own degree of independence, level of engagement, intensity of effort, and amount of learning in online courses?

2. Do students who have taken more online courses demonstrate increased levels of independence, more frequent engagement, higher intensity of effort, and more learning?

3. What are the online learning experiences that students perceive to be most helpful to their education?

\section{Participants}

\section{Methods}

The students in this study attended Abilene Christian University in Abilene, Texas, where Institutional Review Board approval was acquired to conduct this research. The researchers used a convenience sample of 455 students enrolled in an online summer course called BIBT 342 Christianity in Culture. The students were surveyed over three years from 2017 to 2019. Students in 22 different sections of the course participated in the study with class sizes between 19 and 22 students in each online section. Table 1 reports student demographic characteristics. Nearly $60 \%$ of the students who participated were female and just over $40 \%$ were male. The majority of students $(81.3 \%)$ were seniors when taking the course. Juniors made up $17.4 \%$ of students and $1.3 \%$ were sophomores. This course was the first online course ever taken for $9.7 \%$ of students, the second online course for $17.6 \%$ of students, the third for $20.7 \%$ of students, and the fourth online course for $22.0 \%$ of students. A significant number of students $(30.1 \%)$ had already taken 5 or more online courses. 


\section{Table 1}

\begin{tabular}{lr}
\multicolumn{2}{l}{ Participant Characteristics } \\
\hline Variable & $\begin{array}{c}\text { Respondents } \\
(\%)\end{array}$ \\
\hline Sex & \\
Female & $59.3 \%$ \\
Male & $40.7 \%$ \\
Classification & \\
First-year & $0 \%$ \\
Sophomore & $1.3 \%$ \\
Junior & $17.4 \%$ \\
Senior & $81.3 \%$ \\
Number of Online & \\
Courses Taken & \\
1 & $9.7 \%$ \\
2 & $17.6 \%$ \\
3 & $20.7 \%$ \\
4 & $22.0 \%$ \\
5 & $11.4 \%$ \\
$5+$ & $18.7 \%$ \\
\hline
\end{tabular}

This asynchronous course required student completion of various tasks each day in order to progress to the successive assignments throughout the course. The required readings included three books, five articles, and several web pages. Short instructor videos guided students through content as they progressed through the course. Students submitted papers, wrote learning journals, took quizzes, and posted in online discussions. Student participation in discussions required them to make one initial post and respond to two other students' posts within the conversation. A personal learning evaluation at the end of the course served as the instrument for this study.

\section{Instrument}

The survey instrument used was distributed as a final course personal learning evaluation worth $2 \%$ of students' final grades. Each student received full credit (2\%) after the completion of the personal learning evaluation, regardless of their answers. This served as an incentive for students to participate (Gall et al., 1996).

The instructions for the survey were as follows: "This 'quiz' serves primarily as a reflection for you about your learning and it also provides feedback to your faculty member about ways to help improve the student experience in this course in the future. Your grade will not be impacted by how you answer these questions. This is a completion grade. We want your honest feedback."

The personal learning evaluation instrument was assessed for validity by six faculty members who served as a panel of experts prior to its implementation (Leedy \& Ormrod, 2001). Reliability of the instrument was determined by comparing the three survey years and noting no significant differences in answer patterns across the samples. The survey instrument was standardized by being administered consistently in each section through a Canvas Learning Management System end-of-course survey. The choice to use a self-report assessment was made in order to glean students' individual perceptions of their engagement and learning in online 
courses. The survey contained 5 Likert-type questions, four multiple choice demographic questions, two open-ended questions, and one rank order question. The specific questions on the instrument were:

1. During which hours of the day did you complete most of the work for this course? (Choose one) 12am-6am, 6am-9am, 9am-12pm, 12pm-3pm, 3pm-6pm, 6pm-9pm, 9pm$12 \mathrm{am}$

2. From which city and state did you take this course?

3. How many hours a day did you spend working on this course? (Choose one) <30 min., .5-1.0hrs., 1.0-1.5hrs., 1.5-2.0hrs., 2.0-2.5hrs., 2.5-3.0hrs., 3.0-3.5hrs., 3.54.0hrs., 4+

4. Rank in order the following assignments according to how much they helped you learn (1 was the most helpful for your learning and 6 was the least helpful for your learning): Instructor Videos, Course Content, Discussions, Quizzes, Textbooks, Papers

5. What is your classification in school? Senior, Junior, Sophomore

6. How many total online courses have you taken in college? (Choose one) $1,2,3,4,5,5+$

7. In this course I was more engaged as a learner than I usually am in a face-to-face class. 1 (disagree strongly), 2 (disagree), 3 (unsure), 4 (agree), 5 (agree strongly)

8. This course required me to be more proactive and independent as a learner than a faceto-face class. 1 (disagree strongly), 2 (disagree), 3 (unsure), 4 (agree), 5 (agree strongly)

9. I exerted more effort to learn in this course than I typically do in a face-to-face class. 1 (disagree strongly), 2 (disagree), 3 (unsure), 4 (agree), 5 (agree strongly)

10. My instructor did a good job facilitating this course.

1 (disagree strongly), 2 (disagree), 3 (unsure), 4 (agree), 5 (agree strongly)

11. When you think about the amount of information learned in this course, was it equivalent to what you usually learn in a face-to-face class or was it less? 1 (significantly less), 2 (less), 3 (about the same), 4 (more), 5 (significantly more)

12. What is your gender?

\section{Data Analysis}

The data were gathered from students through Canvas, then exported into Excel for analysis, and identifying student information was removed once exported. To answer the first research question, the researchers calculated percentages for student responses to Likert-type questions related to students' feelings of independence, engagement, effort, and amount of 
learning. Bivariate correlations using Pearson's $r$ between all of the variables were used to investigate how independence, engagement, effort, and learning are related (Table 4). The correlation matrix also served to answer the second research question by comparing the total number of students' online courses with the four variables considered. Finally, to answer the third research question, the researchers averaged the rank-order responses to determine student perceptions of course variables most helpful to their learning.

\section{Results}

Table 2 provides the hours of the day that students reported working on the course along with the amount of time spent on the course each day. Students reported working on the course mostly in the evenings: $30.3 \%$ completed most of the work between $6 \mathrm{pm}$ and 9pm, and 30.5\% completed most of the work between $9 \mathrm{pm}$ and midnight. The median amount of time that students spent on course work each day was 2 to 2.5 hours each day.

\section{Table 2}

\section{Time Spent on the Course}

\begin{tabular}{lr}
\hline Variable & Respondents (\%) \\
\hline Hours Worked on Course & $0.9 \%$ \\
12 am to 6 am & $1.1 \%$ \\
6 am to 9 am & $11.9 \%$ \\
9 am to 12 pm & $25.3 \%$ \\
12 pm to 6 pm & $30.3 \%$ \\
6 pm to 9 pm & $30.5 \%$ \\
9 pm to midnight & \\
Amount of Time Spent on Course & \\
Less than 30 minutes a day & $5.2 \%$ \\
30 minutes to 1 hour a day & $12.5 \%$ \\
1 to 1.5 hours a day & $23.7 \%$ \\
1.5 to 2 hours a day & $18.0 \%$ \\
2 to 2.5 hours a day & $17.1 \%$ \\
2.5 to 3 hours a day & $9.7 \%$ \\
3 to 3.5 hours a day & $8.1 \%$ \\
3.5 to 4 hours a day & $5.5 \%$ \\
$4+$ hours a day &
\end{tabular}

In addition to asking questions about student demographics and the amount of time spent working on their course, students were also asked how strongly they agreed or disagreed with the following statements: "This course required me to be more proactive and independent as a learner than a face-to-face class," "In this course I was more engaged as a learner than I usually am in a face-to-face class," and "I exerted more effort to learn in this course than I typically do in a face-to-face class." Students were also asked to respond to the following question: "When you think about the amount of information you learned in this course, was it equivalent to what you usually learn in a face-to-face class or was it less?" Table 3 shows the distribution of student responses to these questions. 
Table 3

Independence, Engagement, Effort, and Learning in the Course

\begin{tabular}{lr}
\hline Variable & Respondents (\%) \\
\hline This course required me to be more proactive and independent as a learner than a & \\
face-to-face class. & $35.2 \%$ \\
Strongly Agree & $49.2 \%$ \\
Agree & $10.1 \%$ \\
Unsure & $4.6 \%$ \\
Disagree & $0.9 \%$ \\
Strongly Disagree & \\
I was more engaged as a learner than I usually am in a face-to-face class. & $13.8 \%$ \\
Strongly Agree & $40.7 \%$ \\
Agree & $24.6 \%$ \\
Unsure & $15.4 \%$ \\
Disagree & $5.5 \%$ \\
Strongly Disagree & \\
I exerted more effort to learn in this course than I typically do in a face-to-face class. & $17.6 \%$ \\
Strongly Agree & $39.8 \%$ \\
Agree & $22.2 \%$ \\
Unsure & $17.4 \%$ \\
Disagree & $3.1 \%$ \\
Strongly Disagree & \\
When you think about the amount of information you learned in this course, was it & \\
equivalent to what you usually learn in a face-to-face class or was it less? & $7.3 \%$ \\
Significantly More & $24.0 \%$ \\
More & $46.2 \%$ \\
About the Same & $19.8 \%$ \\
Less & $2.9 \%$ \\
Significantly Less & \\
\hline &
\end{tabular}

\section{Independence}

Most students (84.4\%) agreed or strongly agreed that this course required them to be more independent and proactive as learners. Those students who reported that the course required them to be more independent as learners spent more time each day on the course, they reported exerting more effort, they said the amount of content learned was equivalent to a typical face-to-face course and were most likely to say their instructor did a good job facilitating the course.

While it is interesting to get a snapshot of student attitudes and behaviors, the survey also allowed us to look for trends and correlations in the data. Table 4 displays a correlation matrix for all variables and several significant correlations are noteworthy. Women report spending more time working on the course each day than men. Seniors spend less time per day, report exerting less effort as compared to a face-to-face class, and report getting less information as compared to face-to-face classes than juniors and sophomores. The number of online courses that a student has taken is positively correlated with both engagement and with perceptions of the amount of information learned, meaning that students with more experience with online learning engage more and feel that they get more information out of the course than students who have taken fewer online courses. 
Students who spent more time each day on the course have significantly higher agreement that they had to be more proactive in the online course than in an average F2F class and they also report exerting more effort in the course. As anticipated, student perceptions of how proactive and independent they had to be, their engagement, the effort they felt was required, and the amount of information learned in this online class as compared to a typical face-to-face course are all highly positively correlated.

\section{Table 4}

\section{Correlation Matrix for All Variables}

\begin{tabular}{|c|c|c|c|c|c|c|c|}
\hline & 1 & 2 & 3 & 4 & 5 & 6 & 7 \\
\hline (1) $\operatorname{Sex}(1=$ Male $)$ & 1 & & & & & & \\
\hline (2) Classification & $0.104 *$ & 1 & & & & & \\
\hline (3) Total Courses & -0.055 & 0.036 & 1 & & & & \\
\hline (4) Time on Course & $-0.128 * *$ & $-0.104 *$ & -0.014 & 1 & & & \\
\hline (5) Engagement & -0.036 & -0.032 & $0.188 * *$ & 0.081 & 1 & & \\
\hline (6) Independence & -0.034 & -0.055 & 0.013 & $0.122 * *$ & $0.361 * *$ & 1 & \\
\hline (7) Effort & -0.051 & $-0.111 *$ & 0.029 & $0.228 * *$ & $0.343 * *$ & $0.371 * *$ & 1 \\
\hline (8) Information Learned & -0.039 & $-0.102 *$ & $0.098 *$ & 0.078 & $0.430 * *$ & $0.267 * *$ & $0.427 * *$ \\
\hline
\end{tabular}

* Significant at the 0.05 level (2-tailed)

** Significant at the 0.01 level (2-tailed)

\section{Engagement}

Over half of students (54.5\%) agreed or strongly agreed that they were more engaged as a learner in this online class than they were in a typical face-to-face class. And those students who had taken more online courses were more likely to report being more engaged. While the definition and interpretation of engagement is often subjective and elusive (Deschaine \& Whale, 2017), it can be defined as a student's individual effort exerted in a class (Stone \& Springer, 2019). This seemed to be the case for these students and is illustrated in Figure 1, which shows the strong similarities between responses about their effort exerted and their level of engagement.

\section{Figure 1}

\section{Engagement and Effort}

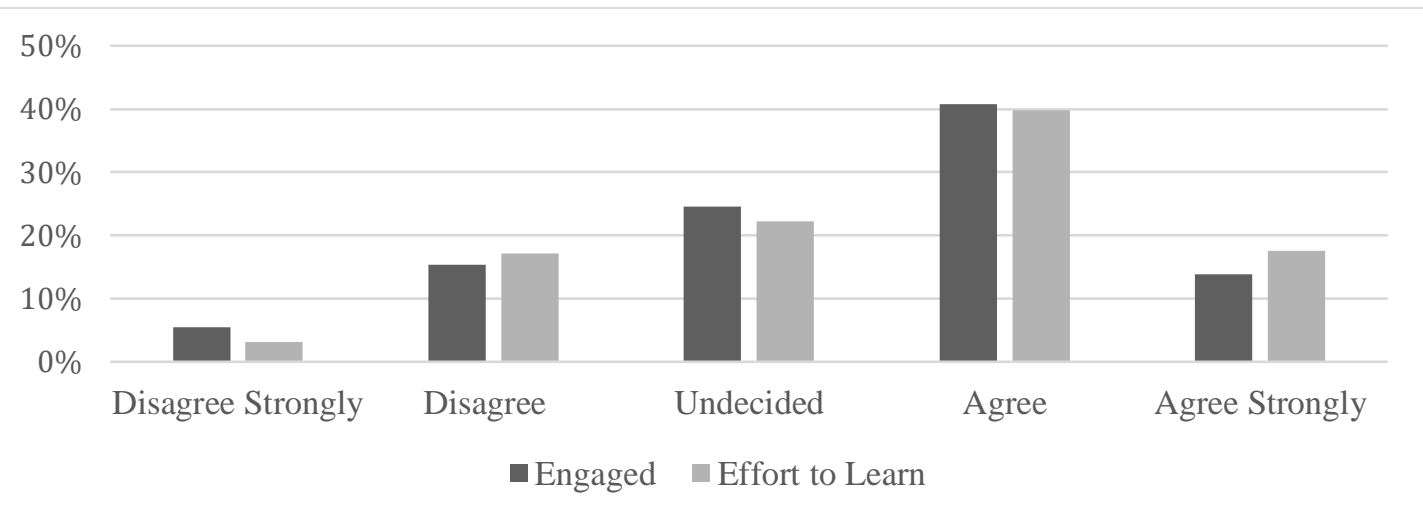




\section{Effort}

In terms of perceived effort, over half of students $(57.4 \%)$ said that they put more effort into the course than the typical face-to-face course. These students were more likely to say they spent more time on coursework each day and that they learned the same amount or more than in a F2F class. While it is difficult to compare all online courses and all F2F courses, this study sought to capture student perceptions of the comparison based on their own experiences. It is worthwhile to note again that the responses to this question about effort and the question about engagement are very similar.

\section{Learning}

Additionally, just over three quarters $(77.5 \%)$ of students said they learned the same amount or more in their online course when compared with a typical F2F class. Just under half said that they learned about the same amount (46.2\%) in this class while a small minority said they learned significantly less $(2.9 \%)$ or significantly more $(7.3 \%)$. These responses plot a belllike curve depicting the reactions of students to the amount of course content learned. While this may say more about the composition and design of the course than the students' effort, any course is an opportunity for inquiry and deep learning for those inspired by that course to propel students to additional learning.

Table 5 lists the number of graded course assignments along with their grade weights. These assignments included taking quizzes with LockDown Browser (over readings and course content provided through video lectures), written assignments, participating in discussions, traditional papers submitted through Turnitin, and finally, learning journals. Only the personal learning evaluation at the end of the course was a completion grade as students received full credit for any answers given.

\section{Table 5}

Summary of Graded Assignments in Course

\begin{tabular}{clc}
\hline Number of Assignments & \multicolumn{1}{c}{ Type of Assignments } & \% of Grade \\
\hline 12 & Quizzes & $39 \%$ \\
6 & Written Assignments & $23 \%$ \\
5 & Discussion Forums & $15 \%$ \\
3 & Papers & $12 \%$ \\
3 & Learning Journals & $09 \%$ \\
1 & Personal Learning Evaluation & $02 \%$ \\
\hline
\end{tabular}

To learn students' perceptions of course tasks, students were asked to rate the various assignments of the course in order from 1 to 6 according to how much the assignment helped them learn (with 1 being most helpful and 6 being least helpful to learning). Table 6 provides the average rating of each of the components of the course. On average, students rated the textbooks and course articles as the most helpful with the content videos being rated as least helpful, although overall a narrow distribution among the averages was evident. 


\section{Table 6}

\begin{tabular}{lr} 
Average Rating of Course Components for Learni \\
\hline Course Components for Learning & Average Rating \\
\hline Textbooks and course articles & 2.73 \\
Group discussions & 3.13 \\
Quizzes & 3.17 \\
Daily instructor feedback video & 3.32 \\
Papers / assignments & 3.53 \\
Course content videos & 3.57 \\
\hline
\end{tabular}

The students surveyed ranked discussions as the second most effective educational tool overall to impact their learning. The value students place on sharing ideas with other students is confirmed in another study of online students who ranked their discussions as first in a list of other learning tools, followed by interactive assignments, specific topics, media/videos, and assignments (Buelow et al., 2018). While many students value sharing ideas in discussions, the similarity in average ranking results in this study for each aspect of the course communicates the diversity of answers to this question. These results align with research suggesting one silver bullet to facilitate student engagement may not exist. Instead, using a diversity of online engagement tasks for students may be best for helping them learn (Dixson, 2010). While textbook (readings) and quizzes were ranked higher in this study as two of the three most helpful tools for their learning, students in other studies have ranked readings and quizzes as the least helpful learning methodologies they encountered in a course (Cundell \& Sheepy, 2018).

\section{Discussion}

\section{Independence}

It is possible that the hidden curriculum of online courses includes lessons in adult learning skills such as being proactive, which is a distinguishing characteristic of adult learning (Knowles et al., 2005). Online courses teach students to be proactive because the methodology of instruction and delivery depends heavily on the initiative of the student to pursue learning. The majority of students in this study perceived that they were required to take more responsibility for their learning than in a typical F2F class. For example, they decided what time of day they would engage in coursework and navigated the expectations of the syllabus while often completing other responsibilities during the course like jobs and home life commitments.

Students who had taken more online courses were more likely to report being more engaged. This may indicate that by taking online courses students are being assimilated into the culture of online learning through adapting to the modality and acquiring the skills to be successful in that context. These students seem to be the ones who understand their roles as assertive participants rather than passive observers to the course. They take responsibility for their learning and appear to receive the most benefit from the course. This aligns with the positive relationship that has been observed between the self-efficacy of students and their overall learning (Landrum, 2020). Teaching students the value of their own initiative and equipping them with online learning strategies is vital to their confidence and success as students.

While adult learners and students who have taken more online classes are generally more self-directed than younger learners, this is not always true of all adults because people approach learning with diverse motivations and maturity (Chen et al., 2018). For this reason, all types of 
students may need coaching on what it means to be self-directed and what they can do to take initiative for their learning (Cox, 2015). This coaching, to be more proactive, should happen early in online courses to give students the greatest chance of success, and it should also continue throughout the course as necessary. Coaching reminds students of their agency in learning in areas such as time management and communication (Martin et al., 2020). But faculty encouragement of student participation should be done in ways that are interpreted by students as positive nudges rather than punitive nagging (Lawrence et al., 2019). Students value instructors who set clear expectations at the beginning of a course, then are responsive and supportive throughout it (Martin \& Bolliger, 2018).

\section{Engagement and Effort}

While a single definition of student engagement remains elusive (Redmond et al., 2018), the student responses to questions about their engagement in this study align very closely with responses to how much effort the students exerted. This was not the case when students were asked about their independence and proactivity as learners compared to a F2F class. Many more students reported that the course required them to be independent $(84.4 \%)$ than said they were engaged $(54.5 \%)$. One possible explanation for this is that students equate effort with engagement in ways that are distinct from being proactive and independent as learners. This is understandable because being proactive and independent as a learner is something that online courses require them to do (You, 2016), while their effort and engagement are things that students choose in any given course.

An important application of this research, then, includes the need to teach students how to be successful in online courses where independence, engagement, and effort positively influence potential learning in the course. Ideally, educators want students to progress from reluctant to assertive engagement. This difference is not always distinguishable by the engagement, but rather by the attitude of the learner approaching the course. This aligns with the sentiment that student engagement requires attentive nurturing and should be constantly assessed (Khan et al., 2017).

This research also has specific applications for faculty members creating online courses to craft opportunities for students to exert effort through engagement and understand their independence (or initiative) in their learning. Instructors can highlight the importance of initiative through communication with students, and inspire initiative through a diverse number of educational experiences for students within the course design (Sato et al., 2019; Stone \& Springer, 2019; Davis et al., 2018). Students' preferences of course strategies for learning in this study were very closely ranked. It is possible that different students had preferences for different learning strategies. The case could be made, then, for the inclusion of multiple learning strategies in online courses to connect with many different students. There may not be one "best" learning strategy. Instead, utilizing an array of methodologies that facilitate interaction may be what helps students learn the best (Nortvig et al., 2018).

\section{Learning}

Just over three quarters $(77.5 \%)$ of students said they learned the same amount or more when compared with a typical F2F class. These results challenge any claims that online courses by default result in less learning for students. Those students who recognized the independence, engagement, and effort required to succeed in the course are the students who enjoyed the most learning. This is not necessarily the case in all online courses because all online courses are not all the same. Nor are all students. This is evident in our results showing greater effort exerted by women in online courses than men, which is counter to results in other studies showing men exert greater effort in online courses (Yang et al., 2011). 


\section{Limitations and Future Research}

One limitation of this research is that it depended on students' own perceptions of their independence, engagement, effort, and learning in online courses. Gathering student perspectives is an important part of educational research (Xiao, 2017; Khan et al., 2017), but it is possible that personal bias led students to claim greater engagement than they exhibited. Future studies could use course analytics to compare student self-reports with the amount of time online to capture a more complete image of their effort in the course. This research also investigated only one online course, albeit across multiple sections and across several years. Future research could compare and contrast courses across disciplines and contrast online and F2F classes with similar outcomes to discern any differences in students' reports of engagement and learning with different course designs. Finally, because the study did not require students to define engagement or identify what led them to feel engaged in the course beyond asking for their ranked preference of learning activities, future research is needed to capture how students define engagement and factors that contribute to feelings of isolation versus engagement.

Finally, the COVID-19 global pandemic of 2020 influenced teaching and learning with technology. While we do not yet know all the ways the world will continue changing, we can surmise that online education is only going to become more common. This research may have been conducted in the last summer when so few students had taken so few online courses. For $10 \%$ of our students, this was their first online course, and for another $28 \%$, it was their second. In the immediate future, students will continue taking multiple online courses, which is why it is vital to continue improving this method of education.

\section{Conclusion}

This research contributes to the field of student engagement in online education in several ways. First, students equate engagement with effort exerted in online classes, and more specifically, they equate engagement with time devoted to their coursework. Second, it is possible to create online courses for students that they perceive to be significant learning experiences where they learn just as much as in a face-to-face course. Teachers accomplish this by incorporating diverse learning activities that are challenging, relevant, and help accomplish course goals. Third, the hidden curriculum of online courses may be the proactivity and independence required to succeed that prepares students to be more successful as adult learners. Instructors can coach students on these expectations through consistent and clear communication so that students do not feel isolated, which leads to discouragement as they become immobilized, but rather feel ownership and independence, which leads to confidence as they take initiative. Finally, it has been said that learning begins with engagement (Shulman, 2002), but it might also be said that learning begins with initiative, which in turn empowers student engagement. 


\section{References}

Al Tawil, R. (2019). Nonverbal communication in text-based, asynchronous online education. International Review of Research in Open and Distributed Learning, 20(1), 144-164. https://eric.ed.gov/?id=EJ1207480

Allen, I. E., Seaman, J., Poulin, R., \& Straut, T. T. (2016). Online report card: Tracking online education in the United States. Babson Survey Research Group. http://onlinelearningsurvey.com/reports/onlinereportcard.pdf

Bawa, P. (2016). Retention in online courses: Exploring issues and solutions-a literature Review. Sage Open, (Jan.-Mar), 1-11.

Bednar, J. (2018). Screen test: Why is online learning seeing a surge in popularity? Business West, 34(26), 32-36.

Bolton, E. C., \& Gregory, S. (2015). Minimizing attrition in online degree Courses. Journal of Educators Online, 12(1), 62-90. https://doaj.org/article/f1edf6c9f2a94fcab9d64ce6d2275cfe

Buelow, J. R., Barry, T., \& Rich, L.E. (2018). Supporting learning engagement with online students. Online Learning, 22(4), 313-340. https://doi.org/10.24059/olj.v22i4.1384

Chen, B., Chang, Y., Ouyang, F., \& Zhou, W. (2018). Fostering student engagement in online discussion through social learning analytics. The Internet and Higher Education, 37, 21-30. https://doi.org/10.1016/j.iheduc.2017.12.002

Choi, B. (2016). How people learn in an asynchronous online learning environment: The relationships between graduate students' learning strategies and learning satisfaction. Canadian Journal of Learning and Technology, 42(1), 1-15. https://eric.ed.gov/?id=EJ1098278

Cohen, J., \& Jackson-Haub, D. (2019). Designing learning for student engagement: An online first year higher education experience. International Journal of Technologies in Learning, 26(2), 35-41. https://doi.org/10.18848/2327-0144/CGP/v26i02/35-41

Collins, K., Groff, S., Mathena, C., \& Kupczynski, L. (2019). Asynchronous video and the development of instructor social presence and student engagement. Turkish Online Journal of Distance Education, 20(1), 53-70. https://eric.ed.gov/?id=EJ1201970

Cox, E. (2015). Coaching and adult learning: Theory and practice. New Directions for Adult and Continuing Education, 148(Winter), 27-38. https://doi.org/10.1002/ace.20149.

Cundell, A., \& Sheepy, E. (2018). Student perceptions of the most effective and engaging online learning activities in a blended graduate seminar, Online Learning, 22(3), 87-102. https://eric.ed.gov/?id=EJ1191493 
Davis, D., Chen, G., Hauff, C., \& Houben, G.-J. (2018). Activating learning at scale: A review of innovations in online learning strategies. Computers and Education, 125(Oct), 327-344. https://doi.org/10.1016/j.compedu.2018.05.019

Deschaine, M. E., \& Whale, D. E. (2017). Increasing student engagement in online educational leadership courses. Journal of Educators Online, 14(1), 36-47.

https://eric.ed.gov/?id=EJ1133612

Dixson, M. (2010). Creating effective student engagement in online courses: What do students find engaging? Journal of the Scholarship of Teaching and Learning, 10(2), 1-13. https://scholarworks.iu.edu/journals/index.php/josotl/article/view/1744/1742

Dumford, A. D., \& Miller, A. L. (2016). Learning online: Unintended consequences for engagement? Hawaii International Conference on Education, Honolulu, HI, January. https://scholarworks.iu.edu/dspace/handle/2022/24109

Everett, D. R. (2015). Adding value: Online student engagement. Information Systems Education Journal, 13(6), 68-76. https://eric.ed.gov/?id=EJ1137356

Fosnacht, K., Copridge, K., \& Sarraf, S. (2017). Peering into the box of grit: How does grit influence engagement in undergraduates? Paper presented at the Association for the Study of Higher Education Annual Conference.

https://www.coursehero.com/file/53643543/ASHE-2017-Fosnacht-Copridgepdf/

Gall, M.D., Borg, W. R., \& Gall, J. P. (1996). Educational research: An introduction. Longman.

Groccia, J. E. (2018). What is student engagement? New Directions for Teaching \& Learning, 154, 11-20. https://doi.org/10.1002/tl.20287

Halverson, L. R., \& Graham, C. R. (2019). Learner engagement in blended learning environments: A conceptual framework. Online Learning, 23(2), 145-78.

https://doi.org/10.24059/olj.v23i2.1481

Indiana University School of Education. (2019). NSSE. Annual results. https://nsse.indiana.edu/NSSE_2019_Results/pdf/NSSE_2019_Annual_Results.pdf

Jackson, Z. (2019). Online education 2.0. Perspectives on History, 57(2), 12-14.

Khan, A., Egbue, O., Palkie, B., \& Madden, J. (2017). Active learning: Engaging students to maximize learning in an online course. Electronic Journal of E-Learning, 15(2), 107-115.

Kahn, P., Everington, L., Kelm, K., Reid, I., \& Watkins, F. (2017). Understanding student engagement in online learning environments: The role of reflexivity. Educational Technology Research \& Development, 65(1), 203-218.

https://doi.org/10.1007/s11423-016-9484-z 
Knowles, M. S., Swanson, R. A., \& Holton, E. F. (2005). The adult learner, 6th ed. Routledge.

Kucuk, S., \& Richardson, J. C. (2019). A structural equation model of predictors of online learners' engagement and satisfaction. Online Learning, 23(2), 196-216. https://doi.org/10.24059/olj.v23i2.1455

Landrum, B. (2020). Examining students' confidence to learn online, self-regulation skills and perceptions of satisfaction and usefulness of online classes. Online Learning Journal, 24(3), 128146. https://doi.org/10.24059/olj.v24i3.2066

Lawrence, J., Brown, A., Redmond, P., \& Basson, M. (2019). Engaging the disengaged: Exploring the use of course-specific learning analytics and nudging to enhance online student engagement. Student Success, 10(2), 47-58. https://doi.org/10.5204/ssj.v10i2.1295

Leedy, P. D., \& J. E. Ormrod. (2001). Practical research planning and design. Merrill Prentice Hall.

Lehman R. M., \& Conceição, S. C. O. (2014). Motivating and retaining online students: Research-based strategies that work. San Francisco: Jossey-Bass.

Martin, F., \& Bolliger, D. U. (2018). Engagement matters: Student perceptions on the importance of engagement strategies in the online learning environment. Online Learning, 22(1), 205-222. https://eric.ed.gov/?id=EJ1179659

Martin, F., Wang, C., \& Sadaf, A. (2018). Student perceptions of helpfulness of facilitation strategies that enhance instructor presence, connectedness, engagement and learning in online courses. The Internet and Higher Education, 37, 52-65. https://doi.org/10.1016/j.iheduc.2018.01.003

Martin, F., Stamper, B., \& Flowers, C. (2020). Examining student perception of readiness for online learning: Importance and confidence. Online Learning Journal, 24(2), 38-58. https://doi.org/10.24059/olj.v24i2.2053

Ng, H. Z., \& Baharom, S. S. (2018). An analysis on adult learners' satisfaction in online education programmes. International Journal of Interactive Mobile Technologies, 12(7), 70-85. https://doi.org/10.3991/ijim.v12i7.9665

Nortvig, A.-M., Petersen, A. K. \& Balle, S. H. (2018). A literature review of the factors influencing e-learning and blended learning in relation to learning outcome, student satisfaction and engagement. Electronic Journal of E-Learning, 16(1), 46-55. https://eric.ed.gov/?id=EJ1175336

Palmer, P. J. (1993). To know as we are known: Education as a spiritual journey. Harper San Francisco. 
Redmond, P., Abawi, L.-A., Brown, A., Henderson, R., \& Heffernan, A. (2018). An online engagement framework for higher education. Online Learning, 22(1), 183-204. https://doi.org/10.24059/olj.v22i1.1175

Sadaf, A., Martin, F., \& Ahlgrim-Delzell, L. (2019). Student perceptions of the impact of quality matters-certified online courses on their learning and engagement. Online Learning, 23(4), 214-233. https://doi.org/10.24059/olj.v23i4.2009

Sarraf, S., Kinzie, J., \& Burch, B. (2019). Measuring quality in online education: A NSSE-QM Collaboration. Association for Institutional Research Annual Forum, Presentation. https://scholarworks.iu.edu/dspace/handle/2022/24142

Sato, T., Ellison, D. W., \& Tsuda, E. (2019). Study habits and learning experiences of undergraduate students in a physical education major online kinesiology course. The Physical Educator, 76, 440-466. https://doi.org/10.18666/TPE-2019-V76-I2-8837

Schroeder-Moreno, M. S. (2010). Enhancing active and interactive learning online lessons learned from an online introductory agroecology course. North American Colleges and Teachers of Agriculture Journal, 54(1), 21-30.

Seaman, J. E., Allen, I. E., \& Seaman, J. (2018). Grade increase: Tracking distance education in the United States. Babson Survey Research Group. https://eric.ed.gov/?id=ED580852

Shrivastava, R., \& Shrivastava, P. S. (2017). Employing adult learning theories in designing a module. Research and Development in Medical Education, 6(2), 64-65.

https://doi.org/10.15171/rdme.2017.014

Shulman, L. (2002). Making differences: A table of learning. Change, 34(6), 36-44.

Smith, S. P. (2017). Adult learning: Effective training methods. Professional Safety, 62(12), 2225 .

Stevenson, T. (2013). Online student persistence: What matters is outside the classroom. Journal of Applied Learning Technology, 3(1), 21-25.

Stone, C., \& Springer, M. (2019). Interactivity, connectedness and 'teacher-presence': Engaging and retaining students online, Australian Journal of Adult Learning, 59(2), 146-169. https://eric.ed.gov/contentdelivery/servlet/ERICServlet?accno=EJ1235966

Stott, P. (2016). The perils of a lack of student engagement: Reflections of a "lonely, brave, and rather exposed" online instructor. British Journal of Educational Technology, 47(1), 51-64. https://doi.org/10.1111/bjet.12215 
Technavio Research (2019). Global academic e-learning market 2019-2023: Growing popularity of online microlearning to boost growth. Business Wire.

https://www.businesswire.com/news/home/20190924005464/en/Global-Academic-E-LearningMarket-2019-2023-Growing-Popularity-of-Online-Microlearning-to-Boost-Growth-Technavio

Xiao, J. (2017). Learner-content interaction in distance education: The weakest link in interaction research. Distance Education, 38(1), 123-135.

https://doi.org/10.1080/01587919.2017.1298982

Yang, Y., Cho, Y., Mathew, S., \& Worth, S. (2011). College student effort expenditure in online versus face-to-face courses: The role of gender, team learning orientation, and sense of classroom community. Journal of Advanced Academics, 22(4), 619-638.

https://doi.org/10.1177/1932202X11415003

Yarbrough, J. R. (2018). Adapting adult learning theory to support innovative, advanced, online learning. Research in Higher Education Journal, 35, 1-15.

https://eric.ed.gov/contentdelivery/servlet/ERICServlet?accno=EJ1194405

You, J. W. (2016). Identifying significant indicators using LMS data to predict course achievement in online learning. The Internet and Higher Education, 29, 23-30.

https://doi.org/10.1016/j.iheduc.2015.11.003 